\title{
Avaliação da imunogenicidade da proteína BYCr (Boophilus Yolk pro-Cathepsin) expressada por vetores eucariotos*
}

\author{
MARIA LÚCIA SCHIAFFINO MEDEIROS \\ Itabajara da Silva Vaz Junior (Orientador - UFRGS) \\ Sandra Estrazulas Farias (Co-orientadora - UFRGS)
}

Banca: Carlos Alexandre Sanchez Ferreira (PUCRS), Claúdio Wageck Canal (UFRGS), Mário Augusto Ono (UEL)

\begin{abstract}
O carrapato Rhipicephalus (Boophilus) microplus é o principal ectoparasita bovino e causa importantes perdas econômicas nas criações de bovino. O controle imunológico é estudado como um método alternativo para seu controle, no entanto, uma vacina eficaz ainda necessita ser desenvolvida. A proteína BYC (Boophilus Yolk Pro-Cathepsin) é uma aspártico proteinase presente no ovo do carrapato e envolvida na embriogênese, já tendo sido testada como imunógeno vacinal. $\mathrm{O}$ propósito deste estudo foi avaliar se a inoculação de plasmídeos para expressão em células eucarióticas (BYCr-PC e BYCrPME) contendo a região codificante para a proteína BYC poderiam gerar uma resposta imune específica. A região codificante da proteína BYC foi amplificada por PCR e clonada em dois vetores de expressão eucariotos (pcDNA3 e pME18Neo). Os clones, BYCr-PC e BYCr-PME foram utilizados para testes de inoculação de camundongos BALB/C por via intramuscular. Os camundongos receberam duas inoculações de $100 \mu \mathrm{g}$ das construções (BYCr-PC ou BYCr-PME) e os controles negativos receberam somente PBS, pcDNA3 ou pME18Neo. A produção de anticorpos, após a inoculação, foi avaliada por Western Blotting e ELISA, sendo detectados anticorpos contra a proteína BYC nos camundongos inoculados com a construção BYCrPC. A imunolocalização da proteína BYC nas amostras de músculo no local da inoculação foram realizadas com o monoclonal BrBm5 (anti-BYC). Estes resultados mostraram que a inoculação com o plasmídeo BYCr-PC induz a produção de anticorpos específicos e possibilita testar o uso de uma vacina de DNA como um método alternativo para o controle de carrapatos.
\end{abstract}

Descritores: Rhipicephalus (Boophilus) microplus, vacina de DNA, vetores de expressão eucariotos, carrapato, BYC (Boophilus Yolk Pro-Cathepsin), embriogênese. 


\title{
Evaluation of rBYC protein immunogenecity expressed with eukaryotic vectors**
}

\author{
MARIA LÚCIA SCHIAFFINO MEDEIROS \\ Itabajara da Silva Vaz Junior (Adviser - UFRGS) \\ Sandra Estrazulas Farias (Co-Adviser - UFRGS)
}

Committee: Carlos Alexandre Sanchez Ferreira (PUCRS), Claúdio Wageck Canal (UFRGS), Mário Augusto Ono (UEL)

The Rhipicephalus (Boophilus) microplus tick is the major bovine ectoparasite and causes important economical losses on cattle breeding. The immunologic control has been studied as an alternative method for the tick control. However, an effective vaccine remains to be developed. BYC (Boophilus Yolk Pro-Cathepsin) is an aspartic proteinase found in eggs that is involved in the embryogenesis of Rhipicephalus (Boophilus) microplus, and it has been proposed as a probable antigen in vaccine development. The purpose of this study was to evaluate whether the immunization containing rBYC (rBYC-PC and rBYC-PME) could elicit a specific anti-BYC immune response in vivo. The cDNA of BYC was amplified by PCR and it was cloned into two eukaryotic expression vectors (pcDNA3 and pME18Neo). The clones, rBYC-PC and rBYC-PME, were produced in large scale for immunoassays. To evaluate the immunogenicity of BYC, BALB/c mice were immunized with DNA vaccine by intramuscular injection. The mice received two intramuscular inoculations of 100ìg plasmids DNA (rBYC-PC or rBYC-PME) and the negative controls received only PBS, pcDNA3 or pME18Neo. The production of antibody after the immunizations was evaluated by Western Blotting and ELISA. Antibodies against BYC in mice inoculated with rBYC-PC were detected. Immunolocalization of the rBYC protein in muscle samples from the injection site with $\mathrm{BBYC}-\mathrm{PC}$ was detected with monoclonal BrBm5 anti-BYC. These results show that DNA immunization produced specific anti-BYC antibodies and suggest that a DNA vaccine could prove useful to develop an alternative method for tick control.

Key words: Rhipicephalus (Boophilus) microplus, DNA vaccine, eukaryotic expression vector, tick, BYC (Boophilus Yolk Pro-Cathepsin), embryogenesis.

\footnotetext{
**Master's Thesis \# 485 (Field: Immunology). 78 p. Graduate Program in Veterinary Sciences [www.ufrgs.br/ppgcv], Faculdade de Veterinária, Universidade Federal do Rio Grande do Sul (UFRGS), Porto Alegre, RS/Brazil. CORRESPONDENCE: M.L.S. Medeiros [maluschiaffino@hotmail.com].
} 